\title{
Estimation of The Combining Ability for Some New White Maize Inbred Lines under Different Environmental Conditions
}

\author{
E.H. El-Seidy, R.A. El-Refaey, A.A. Barkat*, A.A. El- \\ Gammaal and H.A. Aboyousef* \\ Department of Agronomy, Fac. Agric., Tanta Univ., Tanta and \\ "Maize Res. Station, Field Crops Res. Inst., Agric. Res. Canter, \\ Cairo, Egypt.
}

\begin{abstract}
7 HE MAIN objectives of the present study was to estimate the combining ability for some new white maize inbred lines under different environmental conditions and evaluation the $21 \mathrm{~F}_{1}$ crosses come from this study under two plant densities $\left(\mathrm{D}_{1}\right.$ and $\left.\mathrm{D}_{2}\right)$ at two locations $\left(\mathrm{L}_{1}\right.$ and $\left.\mathrm{L}_{2}\right)$. Obtained results could be summarized as follows:

1. The non-additive genetic effects was more important than additive genetic effects in the inheritance of this traits; grain yield at $\mathrm{L}_{1} \mathrm{D}_{1}$, $\mathrm{L}_{1} \mathrm{D}_{2}, \mathrm{~L}_{2} \mathrm{D}_{2}$ and combined data, days to $50 \%$ silking at all environments and combined data, ear height at $\mathrm{L}_{1} \mathrm{D}_{2}$ and 100-kernel weight at $\mathrm{L}_{1} \mathrm{D}_{1}$.

2. The additive gene effects were most responsible for controlling the inheritance of this traits; for grain yield at $\mathrm{L}_{2} \mathrm{D}_{1}$, plant height under all environments and combined data, ear height at $\mathrm{L}_{1} \mathrm{D}_{1}, \mathrm{~L}_{2} \mathrm{D}_{1}, \mathrm{~L}_{2} \mathrm{D}_{2}$ and combined data and 100-kernel weight at $\mathrm{L}_{1} \mathrm{D}_{2}, \mathrm{~L}_{2} \mathrm{D}_{1}, \mathrm{~L}_{2} \mathrm{D}_{2}$ and combined data.

3. The inbred lines; $\mathrm{P}_{1}$ at $\mathrm{L}_{2} \mathrm{D}_{1}, \mathrm{P}_{4}$ at $\mathrm{L}_{1} \mathrm{D}_{2}$ and $\mathrm{P}_{7}$ at $\mathrm{L}_{1} \mathrm{D}_{2}$ had positive and significant $\mathrm{GCA}$ effects for grain yield.

4. The single crosses; $\left(\mathrm{P}_{1} \times \mathrm{P}_{4}\right),\left(\mathrm{P}_{2} \times \mathrm{P}_{6}\right),\left(\mathrm{P}_{2} \times \mathrm{P}_{7}\right),\left(\mathrm{P}_{4} \times \mathrm{P}_{7}\right)$ and $\left(\mathrm{P}_{5} \times\right.$ $\mathrm{P}_{7}$ ) were the best crosses for superiority relative to $\mathrm{SC} 10$ for grain yield.
\end{abstract}

Keywords : Yellow maize, Combining ability, Plant densities.

Maize is one of the most important cereal crops in Egypt. It is used in bread making in rural areas of the country. Also, it is used to feed livestock and poultry either as green fodder and silage or as grains for dry feeding. In addition, it is used in several industries to produce starch, fructose and maize oil. The concept of general (GCA) and specific (SCA) combining ability was introduced by Sprague \& Tatum (1942) and its mathematical modeling was set about by Griffing (1956) in his classical paper in conjunction with the diallel crosses. Mosa (1996) evaluated 10 inbred lines of maize and 45 F1 hybrids among them and revealed that both general and specific combining abilities were significant for ear length, ear diameter, number of kernels/row and grain yield. Amer et al. (1998) revealed that the GCA and SCA mean squares were highly significant for all studied traits, i.e., grain yield, ear length, ear diameter and number of kernels/row. Aly (1999) indicated that both GCA and SCA variances were 
significant for grain yield, ear diameter, ear length and number of kernels/row for the two years and from the combined data over both years. Choukan (1999) indicated that general combining ability effects were highly significant for grain yield and 1000 grains weight. He also added that specific combining ability was significant for grain yield and he concluded that both additive and non-additive effects were found to be important in genetical control of the previous traits. Soliman \& Sadek (1999) observed that five inbred lines exhibited the highest positive and significant GCA effects for grain yield trait. El-Absawy (2002) cleared that GCA mean squares were significant for grain yield per plant, ear diameter and 100 grain weight and also added that the mean squares of SCA were significant for ear diameter and 100 grain weight. El-Shouny et al. (2003) reported that the GCA and SCA mean squares were highly significant for ear diameter, number of kernels/row and grain yield/plant. Meanwhile, the GCA/SCA ratio was larger than unity for all the studied traits except grain yield/plant, indicating that the GCA were important than SCA in the inheritance of these traits. Barakat \& Osman (2008) indicated that the tested inbred lines and testers exhibited significant GCA effects vary greatly according to the studied traits. The variance magnitude due to GCA for tested and tester lines was higher than that due to SCA for all studied traits, this indicates that additive genetic variance was the major source of variation responsible for the inheritance of these traits.

\section{Materials and Methods}

The work of this study was carried out in 2008 and 2009 summer seasons at both of Gemmeiza and Sids Agriculture Research Stations of the Agriculture Research Center (A.R.C.), Egypt . Half diallel cross among seven white maize inbred lines were made at Gemmeiza Research Station during the growing season 2008 . Name and origin of these inbred lines are presented in Table 1. The half diallel crossings among the seven white inbred lines was carried out producing 21 white single crosses in 2008 season. In 2009 season, the $21 \mathrm{~F}_{1}$ white hybrids and two checks (single cross 10 and single cross 122 ) were evaluated at two locations, i.e. Gemmeiza $\left(\mathrm{L}_{1}\right)$ and Sids $\left(\mathrm{L}_{2}\right)$ Agricultural Research Stations under two plant densities, i.e. 26,250 $\left(\mathrm{D}_{1}\right)$ and $21,000\left(\mathrm{D}_{2}\right)$ plant per feddan. The whole study was designated as four different environmental conditions $\left(\mathrm{L}_{1} \mathrm{D}_{1}, \mathrm{~L}_{1} \mathrm{D}_{2}, \mathrm{~L}_{2} \mathrm{D}_{1}\right.$ and $\left.\mathrm{L}_{2} \mathrm{D}_{2}\right)$.

TABLE 1. The name and origin of the seven white inbred lines (part 1).

\begin{tabular}{|l|c|c|}
\hline No. of parent & Name & Origin \\
\hline$P_{1}$ & Gemmeiza 170 & (Gz. 2- Ev. 60) \\
\hline$P_{2}$ & Gemmeiza 169 & (Gm.W.Pop.) \\
\hline$P_{3}$ & Gemmeiza 193 & (Laposta) \\
\hline$P_{4}$ & Gemmeiza 218 & (Tuxpino) \\
\hline$P_{5}$ & Gemmeiza 120 & (Tep. \# 5) \\
\hline$P_{6}$ & Gemmeiza 80 & (AED.) \\
\hline$P_{7}$ & Gemmeiza 175 & (Gz. 2- Ev. 60) \\
\hline
\end{tabular}

Egypt. J. Agron. 34, No. 2 (2012) 


\section{Experimental design and cultural practices}

The four environmental conditions mentioned above were designated as; $\mathrm{L}_{1} \mathrm{D}_{1}, \mathrm{~L}_{1} \mathrm{D}_{2}, \mathrm{~L}_{2} \mathrm{D}_{1}$ and $\mathrm{L}_{2} \mathrm{D}_{2}$. In each environment, a randomized complete block design with three replications was used. Each plot consisted of one row, $5 \mathrm{~m}$ long, $80 \mathrm{~cm}$ width and the hills were spaced $20 \mathrm{~cm}$ apart in $\mathrm{D}_{1}(26,250$ plant per feddan) and $25 \mathrm{~cm}$ apart in $\mathrm{D}_{2}$ (21,000 plant per feddan). All cultural practices were applied as recommended. The genetic analysis for the diallel crosses was computed according to Griffing (1956) Method -4 , Modle -1 , for all studied traits.

\section{Results and Discussion}

\section{Analysis of variance}

The analysis of variance for five traits (days to $50 \%$ silking, plant height, ear height, 100-kernel weight and grain yield ) under four environmental conditions and combined data are presented in Table 2.

Environments mean squares for all studied traits were highly significant. These results indicated that there were overall differences between the four environmental conditions. The differences among the partition locations (L) showed significant for all studied traits, except grain yield, meaning that all studied traits affected by locations. These results are agreement with Barakat et al. (2003). Data in Table 2 appeared that, the mean squares of densities (D) were significant for plant height, ear height and grain yield, while the mean squares of locations $\mathrm{x}$ densities interaction ( $\mathrm{L}$ x D) were significant for plant height and ear height.

The mean squares among crosses were highly significant for all traits under four environmental conditions and combined data. This means that there were differences among the crosses under four environments and the combined data for all traits. These results are agreement with those of Mosa (2005), Mosa et al. (2006) and Motawei (2006). The interaction between crosses with the partitions; locations (L), densities (D) and (LxD) interactions were significant, except the interaction between crosses with locations and (LxD) interactions for grain yield. Meaning that the crosses were affected by change of locations, densities and interaction locations $\mathrm{x}$ densities for all traits except grain yield. These results are agreement with Barakat et al. (2003) and Barakat \& Osman (2008). 
Egypt. J. Agron. 34, No. 2 (2012) 
ESTIMATION OF THE COMBINING ABILITY...

Egypt. J. Agron. 34, No. 2 (2012) 


\section{Mean performance}

The best environment condition of crosses for plant height and ear height was $\mathrm{L}_{2} \mathrm{D}_{2}$ (Sids location $\left(\mathrm{L}_{2}\right)$ and 21,000 plants/Fed $\left(\mathrm{D}_{2}\right)$ ), while for days to $50 \%$ silking, and 100-kernel weight were $\mathrm{L}_{1} \mathrm{D}_{2}$ (Gemmeiza location $\left(\mathrm{L}_{1}\right)$ and 21,000 plants/fed $\left.\left(\mathrm{D}_{2}\right)\right)$. Gemmeiza location $\left(\mathrm{L}_{1}\right)$ was suitable location for traits; days to $50 \%$ silking and 100-kernel weight, while the suitable location for traits; plant height and ear height was Sids location. The density 21,000 plants/fed $\left(\mathrm{D}_{2}\right)$ was more suitable for all studied traits, except days to $50 \%$ silking. The density 26.250 plants/fed $\left(D_{1}\right)$ was more suitable (Table 3 ).

TABLE 3. Mean performance and coefficient of variability (C.V\%) for five traits at four different environments and their combined data.

\begin{tabular}{|c|c|c|c|c|c|c|c|c|c|}
\hline \multirow[b]{2}{*}{ Mean } & \multicolumn{4}{|c|}{ Environmental condition } & \multicolumn{2}{|c|}{ Locations } & \multicolumn{2}{|c|}{ Densities } & \multirow[b]{2}{*}{ Combined } \\
\hline & $\mathbf{L}_{1} \mathbf{D}_{1}$ & $\mathbf{L}_{1} \mathbf{D}_{2}$ & $\mathbf{L}_{2} \mathbf{D}_{1}$ & $\mathbf{L}_{2} \mathbf{D}_{2}$ & $\mathbf{L}_{1}$ & $\mathbf{L}_{2}$ & $\mathbf{D}_{1}$ & $\mathbf{D}_{2}$ & \\
\hline \multicolumn{10}{|c|}{ Days to $50 \%$ silking } \\
\hline Crosses & 63.03 & 62.87 & 70.67 & 71.20 & 62.95 & 70.93 & 66.85 & 67.03 & 66.94 \\
\hline Checks & 64.84 & 63.00 & 74.50 & 72.00 & 63.92 & 73.25 & 69.67 & 67.50 & 68.59 \\
\hline $\mathrm{CV} \%$ & 1.31 & 1.39 & 1.51 & 1.36 & 1.35 & 1.44 & 1.41 & 1.38 & 1.40 \\
\hline \multicolumn{10}{|c|}{ Plant height } \\
\hline Crosses & 251.35 & 244.02 & 241.35 & 229.13 & 247.68 & 235.24 & 246.35 & 236.57 & 241.46 \\
\hline Checks & 276.2 & 266.7 & 247.5 & 248.3 & 271.45 & 247.90 & 261.85 & 257.50 & 259.67 \\
\hline $\mathrm{CV} \%$ & 2.55 & 2.22 & 2.06 & 2.12 & 2.40 & 2.09 & 2.33 & 2.17 & 2.26 \\
\hline \multicolumn{10}{|c|}{ Ear height } \\
\hline Crosses & 141.94 & 126.73 & 131.52 & 121.21 & 134.33 & 126.37 & 136.73 & 123.99 & 130.35 \\
\hline Checks & 158.83 & 156.67 & 141.65 & 127.5 & 157.75 & 134.58 & 150.24 & 142.09 & 146.17 \\
\hline $\mathrm{CV} \%$ & 2.89 & 4.88 & 3.42 & 4.42 & 3.90 & 3.91 & 3.15 & 4.66 & 3.91 \\
\hline \multicolumn{10}{|c|}{ 100- kernel weight } \\
\hline Crosses & 36.50 & 36.69 & 34.76 & 34.98 & 36.67 & 34.87 & 35.71 & 35.84 & 35.77 \\
\hline Checks & 39.02 & 38.15 & 34.33 & 35.83 & 38.58 & 35.08 & 36.68 & 36.99 & 36.83 \\
\hline $\mathrm{CV} \%$ & 5.51 & 4.28 & 609.00 & 4.93 & 4.94 & 6.32 & 5.79 & 5.48 & 5.64 \\
\hline \multicolumn{10}{|c|}{ Grain yield } \\
\hline Crosses & 37.460 & 32.310 & 37.780 & 32.710 & 34.890 & 35.240 & 37.620 & 32.510 & 35.070 \\
\hline Checks & 36.223 & 31.997 & 33.832 & 31.432 & 34.110 & 32.632 & 35.027 & 31.714 & 33.371 \\
\hline $\mathrm{CV} \%$ & 9.87 & 11.58 & 11.89 & 12.32 & 10.73 & 12.11 & 10.88 & 11.95 & 11.48 \\
\hline
\end{tabular}


For grain yield, the highest value for crosses was obtained in $\mathrm{L}_{2} \mathrm{D}_{1}(37.780$ ard/ fed), while the lowest value was detected in $\mathrm{L}_{1} \mathrm{D}_{2}(32.310$ ard / fed). On the other hand, the highest and lowest values for checks were obtained in $L_{1} D_{1}$ (36.223 ard/ fed) and $\mathrm{L}_{2} \mathrm{D}_{2}(31.432 \mathrm{ard} / \mathrm{fed})$, respectively. This is showing that $L_{2} D_{1}$ is the best environment for crosses. The Table 3 below exhibited that $D_{1}$ (37.620 ard/ fed) gave higher value than $\mathrm{D}_{2}(32.510 \mathrm{ard} / \mathrm{fed})$, because; high plant density encourages yield. The superiority of grain yield /fed in dense sowing could be attributed to the higher number of ears per unit area which reverse the effect of the increasing in the grain yield /fed. This agree with what obtained by Said \& Gabr (1999), Marchao et al. (2005), who reported that increasing in plant density is leading to increasing in yield per fedden. $\mathrm{L}_{2}(35.240 \mathrm{ard} / \mathrm{fed})$ was better than $\mathrm{L}_{1}(34.890 \mathrm{ard} / \mathrm{fed})$ in the same direction. Mean performance of $21 \mathrm{~F}_{1}$ crosses and two checks SC10 and SC 122 for grain yield under different environments and their combined are shown in Table 4 . The means of crosses ranged from 31.640 ard / fed $\left(\mathrm{P}_{5} \times \mathrm{P}_{6}\right)$ to 45.740 ard / fed $\left(\mathrm{P}_{5} \times \mathrm{P}_{7}\right)$, from 25.997 ard / fed $\left(\mathrm{P}_{3} \times \mathrm{P}_{7}\right)$ to 40.304 ard $/$ fed $\left(\mathrm{P}_{4} \times \mathrm{P}_{7}\right)$, from 30.872 ard $/$ fed $\left(\mathrm{P}_{2} \times \mathrm{P}_{4}\right)$ to 45.351 ard $/$ fed $\left(\mathrm{P}_{1} \times\right.$ $\left.\mathrm{P}_{4}\right)$, from 25.492 ard /fed $\left(\mathrm{P}_{2} \times \mathrm{P}_{5}\right)$ to 39.784 ard $/$ fed $\left(\mathrm{P}_{5} \times \mathrm{P}_{7}\right)$ and from 30.404 ard /fed $\left(\mathrm{P}_{3} \times \mathrm{P}_{7}\right)$ to 40.736 ard / fed $\left(\mathrm{P}_{5} \times \mathrm{P}_{7}\right)$ at $\mathrm{L}_{1} \mathrm{D}_{1}, \mathrm{~L}_{1} \mathrm{D}_{2}, \mathrm{~L}_{2} \mathrm{D}_{1}, \mathrm{~L}_{2} \mathrm{D}_{2}$ and combined data, respectively. On the other hand, the cross; $\left(\mathrm{P}_{4} \times \mathrm{P}_{7}\right)$ at $\mathrm{L}_{1} \mathrm{D}_{1}, \mathrm{~L}_{1} \mathrm{D}_{2}$ and combined data, the cross; $\left(\mathrm{P}_{5} \times \mathrm{P}_{7}\right)$ at $\mathrm{L}_{1} \mathrm{D}_{1}, \mathrm{~L}_{2} \mathrm{D}_{2}$ and combined data, the cross; $\left(\mathrm{P}_{1} \times \mathrm{P}_{4}\right)$ at $\mathrm{L}_{2} \mathrm{D}_{1}$ and combined data, the cross; $\left(\mathrm{P}_{2} \times \mathrm{P}_{7}\right)$ at $\mathrm{L}_{2} \mathrm{D}_{2}$ and combined data and the crosses; $\left(\mathrm{P}_{1} \times \mathrm{P}_{5}\right),\left(\mathrm{P}_{2} \times \mathrm{P}_{6}\right)$ and $\left(\mathrm{P}_{4} \times \mathrm{P}_{5}\right)$ at $\mathrm{L}_{2} \mathrm{D}_{1}$, combined data and $\mathrm{L}_{2} \mathrm{D}_{1}$, respectively exhibited significant to highly significant values for grain yield compared with the highest check SC 10.

\section{Combining ability}

Analysis of variance

The analysis of variance for genetic components of crosses and their possible interactions with different environments and combined data for nine traits were presented in Table 5.

The results in Table 5 showed that, the variances among crosses are partitioned to GCA and SCA variances. Results showed that crosses variance were highly significant, indicating that crosses varied significantly from each others. Also, the results revealed that mean squares due to general combining ability (GCA) and specific combining ability (SCA) were significant and highly significant for all traits under all environments and combined data, except mean squares of GCA for days to $50 \%$ silking and grain yield at $\mathrm{L}_{2} \mathrm{D}_{2}$ and combined data, while SCA mean squares were insignificant for 100 -kernel weight at $L_{2} \mathrm{D}_{2}$ and combined data and grain yield at $\mathrm{L}_{2} \mathrm{D}_{1}$. Results referred that both additive and non-additive effects were important in controlling of traits. These results are in agreement with those obtained by El-Shenawy \& Tolba (2001), Abd El-Aty \& Katta (2002), Yousif et al. (2003), Mosa \& Amer (2004) and Mosa (2005). On the other side, the interaction between GCA and SCA with their partitions (L, D and L x D) were significant to highly significant for all traits, except GCA x locations (L) for days to $50 \%$ silking and grain yield, indicating that the additive and non additive gene effects were affected by the environmental conditions. These results are in agreement with Mosa (2003) and Motawei (2006) found significant interaction between specific combining ability with locations for grain yield. 
Egypt. J. Agron. 34, No. 2 (2012) 
ESTIMATION OF THE COMBINING ABILITY... 
Egypt. J. Agron. 34, No. 2 (2012) 
ESTIMATION OF THE COMBINING ABILITY...

Egypt. J. Agron. 34, No. 2 (2012) 
Regarding GCA / SCA ratio, Table 5 appeared that, the ratio of GCA/ SCA was less than unity for days to $50 \%$ silking at all environments and combined data, ear height at $\mathrm{L}_{1} \mathrm{D}_{2}, 100$-kernel weight at $\mathrm{L}_{1} \mathrm{D}_{1}$ and grain yield at $\mathrm{L}_{1} \mathrm{D}_{1}, \mathrm{~L}_{1} \mathrm{D}_{2}$, $\mathrm{L}_{2} \mathrm{D}_{2}$ and combined data, indicating that the non-additive genetic effects were more important than additive genetic effects in the inheritance of these traits. Mosa (2003), Motawei (2006), Mosa (2006) and Mosa et al. (2006) found that non-additive gene action was more important expression for grain yield. On the other side, GCA / SCA was more than unity for plant height under all environments and combined data, ear height at $\mathrm{L}_{1} \mathrm{D}_{1}, \mathrm{~L}_{2} \mathrm{D}_{1}, \mathrm{~L}_{2} \mathrm{D}_{2}$ and combined data, 100 kernels weight at $\mathrm{L}_{1} \mathrm{D}_{2}, \mathrm{~L}_{2} \mathrm{D}_{1}, \mathrm{~L}_{2} \mathrm{D}_{2}$ and combined data and grain yield at $\mathrm{L}_{2} \mathrm{D}_{1}$, meaning that the additive gene effects were most responsible for controlling the inheritance of these traits. Regarding Table 5 showed that, the ratio GCA x L / SCA x L was less than unity for all traits, except plant height and ear height, meaning that the non additive gene effects were more interacted than additive gene with locations. Barakat et al. (2003) found that the non additive gene effects were more interacted with locations for grain yield and days to $50 \%$ silking. The ratio GCA x D / SCA x D was more than unity for plant height, ear height and 100 -kernels weight, while it was less than unity for another traits. On the other hand, the ratio GCA x L x D / SCA x L x D was less than unity for all traits, except for plant height and ear height.

\section{General combining ability}

Estimation of GCA effects for nine traits at four environments and combined data are presented in Table 6 .

For days to $50 \%$ silking, the inbred line $\left(\mathrm{P}_{1}\right)$ had desirable negative values and significant for GCA effects under all environments and combined data, except $L_{2} D_{2}$. Results indicated that this inbreed line could be effective in selection program for the desirable silking date (toward earliness).

Considering plant height, $\mathrm{P}_{1}$ exhibited highly significant for GCA effects towards shortness under four environments and the combined data, also $\mathrm{P}_{2}$ at $\mathrm{L}_{1} \mathrm{D}_{1}, \mathrm{~L}_{1} \mathrm{D}_{2}, \mathrm{~L}_{2} \mathrm{D}_{1}$ and the combined data, $\mathrm{P}_{5}$ at $\mathrm{L}_{1} \mathrm{D}_{1}, \mathrm{~L}_{1} \mathrm{D}_{2}$ and the combined data and $\mathrm{P}_{3}$ at $\mathrm{L}_{1} \mathrm{D}_{2}$ and $\mathrm{L}_{2} \mathrm{D}_{2}$.

Concerning ear height, Table 6 cleared that, the inbred lines $\mathrm{P}_{1}$ at $\mathrm{L}_{1} \mathrm{D}_{1}$, $\mathrm{L}_{2} \mathrm{D}_{1}, \mathrm{~L}_{2} \mathrm{D}_{2}$ and combined data, $\mathrm{P}_{2}$ at $\mathrm{L}_{1} \mathrm{D}_{1}, \mathrm{~L}_{2} \mathrm{D}_{1}$ and combined data, $\mathrm{P}_{3}$ at $\mathrm{L}_{1} \mathrm{D}_{2}$ and $\mathrm{L}_{2} \mathrm{D}_{2}$ and $\mathrm{P}_{5}$ and $\mathrm{P}_{6}$ at $\mathrm{L}_{1} \mathrm{D}_{1}$ and $\mathrm{L}_{1} \mathrm{D}_{2}$, respectively exhibited highly significant for low ear position.

For 100-kernel weight, the inbred line $\mathrm{P}_{1}$ at $\mathrm{L}_{2} \mathrm{D}_{1}, \mathrm{P}_{3}$ at $\mathrm{L}_{1} \mathrm{D}_{2}$ and $\mathrm{P}_{7}$ at $\mathrm{L}_{2} \mathrm{D}_{1}$ and $\mathrm{L}_{2} \mathrm{D}_{2}$ had desirable values and significant of GCA effects for this trait .

For grain yield, Table 6 cleared that, $\mathrm{P}_{1}$ at $\mathrm{L}_{2} \mathrm{D}_{1}, \mathrm{P}_{4}$ at $\mathrm{L}_{1} \mathrm{D}_{2}$ and $\mathrm{P}_{7}$ at $\mathrm{L}_{1} \mathrm{D}_{2}$ had desirable positive and significant GCA effects for this trait. 
ESTIMATION OF THE COMBINING ABILITY... 
Egypt. J. Agron. 34, No. 2 (2012) 
Specific combining ability

Estimation of SCA effects for five traits at four environmental conditions and their combined data are presented in Table 7.

Regarding days to $50 \%$ silking, Table 7 appeared that, two crosses; $\mathrm{P}_{2} \times \mathrm{P}_{7}$ and $\mathrm{P}_{3} \times \mathrm{P}_{5}$ under all environmental conditions and combined data, one cross; $\mathrm{P}_{1} \times \mathrm{P}_{7}$ at $\mathrm{L}_{1} \mathrm{D}_{2}$ and $\mathrm{L}_{2} \mathrm{D}_{2}$, two crosses; $\mathrm{P}_{2} \times \mathrm{P}_{3}$ and $\mathrm{P}_{4} \times \mathrm{P}_{7}$ at $\mathrm{L}_{1} \mathrm{D}_{1}$ and $\mathrm{L}_{1} \mathrm{D}_{2}$, one cross; $\mathrm{P}_{1} \times \mathrm{P}_{4}$ at $\mathrm{L}_{2} \mathrm{D}_{2}$ and combined data, $\mathrm{P}_{2} \times \mathrm{P}_{4}$ at $\mathrm{L}_{2} \mathrm{D}_{1}$ and $\mathrm{L}_{2} \mathrm{D}_{2}$, three crosses; $\mathrm{P}_{2} \times \mathrm{P}_{6}, \mathrm{P}_{3} \times \mathrm{P}_{6}$ and $\mathrm{P}_{5} \times \mathrm{P}_{7}$ at $\mathrm{L}_{1} \mathrm{D}_{2}$ and $\mathrm{P}_{6} \times \mathrm{P}_{7}$ at $\mathrm{L}_{1} \mathrm{D}_{1}$ exhibited desirable SCA effects towards earliness.

For plant height, Table 7 cleared that, the cross; $\mathrm{P}_{3} \times \mathrm{P}_{4}$ at $\mathrm{L}_{1} \mathrm{D}_{1}, \mathrm{~L}_{1} \mathrm{D}_{2}, \mathrm{~L}_{2} \mathrm{D}_{2}$ and combined data, cross; $\mathrm{P}_{6} \times \mathrm{P}_{7}$ at $\mathrm{L}_{1} \mathrm{D}_{1}, \mathrm{~L}_{1} \mathrm{D}_{2}$ and combined data, cross; $\mathrm{P}_{5} \mathrm{x}$ $\mathrm{P}_{7}$ at $\mathrm{L}_{1} \mathrm{D}_{2}$ and $\mathrm{L}_{2} \mathrm{D}_{2}$, cross; $\mathrm{P}_{1} \times \mathrm{P}_{4}$ at $\mathrm{L}_{1} \mathrm{D}_{2}, \mathrm{~L}_{2} \mathrm{D}_{2}$ and combined data, crosses; $\mathrm{P}_{1} \times \mathrm{P}_{3}$ and $\mathrm{P}_{2} \times \mathrm{P}_{6}$ at $\mathrm{L}_{1} \mathrm{D}_{1}$ and $\mathrm{L}_{2} \mathrm{D}_{1}$, cross; $\mathrm{P}_{3} \times \mathrm{P}_{5}$ at $\mathrm{L}_{1} \mathrm{D}_{1}$ and $\mathrm{L}_{1} \mathrm{D}_{2}$, cross; $\mathrm{P}_{2} \times$ $\mathrm{P}_{4}$ at $\mathrm{L}_{1} \mathrm{D}_{2}$ and $\mathrm{L}_{2} \mathrm{D}_{1}$, cross; $\mathrm{P}_{1} \times \mathrm{P}_{5}$ at $\mathrm{L}_{2} \mathrm{D}_{1}$ and $\mathrm{L}_{2} \mathrm{D}_{2}$, cross; $\mathrm{P}_{5} \times \mathrm{P}_{6}$ at $\mathrm{L}_{1} \mathrm{D}_{1}$ and $\mathrm{L}_{2} \mathrm{D}_{1}$ crosses; $\mathrm{P}_{1} \times \mathrm{P}_{6}, \mathrm{P}_{2} \times \mathrm{P}_{3}$ and $\mathrm{P}_{4} \times \mathrm{P}_{7}$ at $\mathrm{L}_{1} \mathrm{D}_{1}$ and crosses; $\mathrm{P}_{2} \times \mathrm{P}_{7}$ and $\mathrm{P}_{3} \times \mathrm{P}_{6}$ at $L_{2} D_{2}$ had significant and highly significant for SCA effects towards shortness.

Referring ear height, 9 crosses at $\mathrm{L}_{1} \mathrm{D}_{1}, 6$ crosses at $\mathrm{L}_{1} \mathrm{D}_{2}$ and $\mathrm{L}_{2} \mathrm{D}_{1}, 8$ at $\mathrm{L}_{2} \mathrm{D}_{2}$ and 5 crosses; $\left(\mathrm{P}_{1} \times \mathrm{P}_{3}, \mathrm{P}_{3} \times \mathrm{P}_{4}, \mathrm{P}_{4} \times \mathrm{P}_{7}, \mathrm{P}_{5} \times \mathrm{P}_{6}\right.$ and $\left.\mathrm{P}_{6} \times \mathrm{P}_{7}\right)$ at the combined data had desirable values (negative and significant) of SCA effects for low ear position.

Regarding 100-kernel weight, at $\mathrm{L}_{1} \mathrm{D}_{1}$ the crosses; $\left(\mathrm{P}_{1} \times \mathrm{P}_{4}, \mathrm{P}_{1} \times \mathrm{P}_{5}, \mathrm{P}_{2} \times \mathrm{P}_{6}\right.$, $\mathrm{P}_{3} \times \mathrm{P}_{5}$ and $\left.\mathrm{P}_{4} \times \mathrm{P}_{7}\right)$, at $\mathrm{L}_{1} \mathrm{D}_{2}$ the crosses; $\left(\mathrm{P}_{1} \times \mathrm{P}_{4}, \mathrm{P}_{1} \times \mathrm{P}_{5}, \mathrm{P}_{2} \times \mathrm{P}_{6}\right.$ and $\left.\mathrm{P}_{3} \times \mathrm{P}_{5}\right)$ and at $L_{2} D_{1}$ the cross; $\left(P_{1} \times P_{6}\right)$ given desirable values and significant of SCA effects for 100 - kernel weight. The obtained results were in good harmony with those reported by Shafey et al. (2003) and Singh \& Roy (2007).

For grain yield, the crosses; $\mathrm{P}_{2} \times \mathrm{P}_{6}$ and $\mathrm{P}_{3} \times \mathrm{P}_{6}$ exhibited significant and highly significant desirable SCA effects for grain yield under all environmental conditions and combined data, except for $\mathrm{L}_{2} \mathrm{D}_{1}$. While, the crosses; $\mathrm{P}_{1} \times \mathrm{P}_{4}$ and $\mathrm{P}_{5} \times \mathrm{P}_{7}$ had positive highly significant SCA effects at $\mathrm{L}_{1} \mathrm{D}_{2}$ and $\mathrm{L}_{2} \mathrm{D}_{2}$ and combined data. The crosses; $\mathrm{P}_{1} \times \mathrm{P}_{3}$ at $\mathrm{L}_{1} \mathrm{D}_{2}, \mathrm{P}_{4} \times \mathrm{P}_{7}$ at $\mathrm{L}_{1} \mathrm{D}_{1}$ and $\mathrm{L}_{1} \mathrm{D}_{2}$ and $\mathrm{P}_{1} \times$ $\mathrm{P}_{5}$ at $\mathrm{L}_{2} \mathrm{D}_{2}$ acted in the same manner Table 7 .

\section{Superiority percentages}

Superiority percentages related to two checks SC10 and SC122 for the 21 $\mathrm{F}^{1 \mathrm{~s}}$ crosses under combined data are presented in Table 8 .

Regarding days to $50 \%$ silking, Table 8 appeared that, all the crosses superiority relative to $\mathrm{SC} 10$, except $\mathrm{P}_{3} \times \mathrm{P}_{7}$, while 9 crosses; $\left(\mathrm{P}_{1} \times \mathrm{P}_{3}, \mathrm{P}_{1} \times \mathrm{P}_{4}\right.$, $\mathrm{P}_{1} \times \mathrm{P}_{6}, \mathrm{P}_{1} \times \mathrm{P}_{7}, \mathrm{P}_{2} \times \mathrm{P}_{3}, \mathrm{P}_{2} \times \mathrm{P}_{4}, \mathrm{P}_{2} \times \mathrm{P}_{7}, \mathrm{P}_{3} \times \mathrm{P}_{5}$ and $\mathrm{P}_{3} \times \mathrm{P}_{6}$ ) superiority relative to $\mathrm{SC} 122$. 
Egypt. J. Agron. 34, No. 2 (2012) 
ESTIMATION OF THE COMBINING ABILITY...

Egypt. J. Agron. 34, No. 2 (2012) 
E.H. EL-SEIDY et al.

Egypt. J. Agron. 34, No. 2 (2012) 
For plant height, Data in Table 8 showed that, all the crosses superiority for shortness relative to $\mathrm{SC10}$,except cross $\mathrm{P}_{4} \times \mathrm{P}_{6}$, also 16 crosses; $\left(\mathrm{P}_{1} \times \mathrm{P}_{2}, \mathrm{P}_{1} \mathrm{x}\right.$ $\mathrm{P}_{3}, \mathrm{P}_{1} \times \mathrm{P}_{4}, \mathrm{P}_{1} \times \mathrm{P}_{5}, \mathrm{P}_{1} \times \mathrm{P}_{6}, \mathrm{P}_{1} \times \mathrm{P}_{7}, \mathrm{P}_{2} \times \mathrm{P}_{3}, \mathrm{P}_{2} \times \mathrm{P}_{4}, \mathrm{P}_{2} \times \mathrm{P}_{5}, \mathrm{P}_{2} \times \mathrm{P}_{6}, \mathrm{P}_{2} \times \mathrm{P}_{7}, \mathrm{P}_{3} \times$ $\mathrm{P}_{4}, \mathrm{P}_{3} \times \mathrm{P}_{5}, \mathrm{P}_{5} \times \mathrm{P}_{6}, \mathrm{P}_{5} \times \mathrm{P}_{7}$ and $\mathrm{P}_{6} \times \mathrm{P}_{7}$ ) superiority relative to $\mathrm{SC} 122$.

Concerning ear height, Table 8 cleared that, all the crosses superiority for low ear position relative to $\mathrm{SC} 10$ and $\mathrm{SC} 122$, except crosses; $\left(\mathrm{P}_{3} \times \mathrm{P}_{7}\right.$ and $\left.\mathrm{P}_{4} \times \mathrm{P}_{6}\right)$ for SC 10 and $\left(\mathrm{P}_{3} \times \mathrm{P}_{6}, \mathrm{P}_{3} \times \mathrm{P}_{7}, \mathrm{P}_{4} \times \mathrm{P}_{5}\right.$ and $\left.\mathrm{P}_{4} \times \mathrm{P}_{6}\right)$ for $\mathrm{SC} 122$. The obtained results are in good agreement with those reported by Hammouda (2002), Singh et al. (2002), El-Gazzar (2004), EL-Hosary \& EL-Badawy (2005) and Mosa (2006).

For 100-kernel weight, data in Table 8 exhibited relative to SC. 10 no crosses had positive superiority percentage for this trait, while relative to SC 122 nine crosses; $\left(\mathrm{P}_{1} \times \mathrm{P}_{3}, \mathrm{P}_{1} \times \mathrm{P}_{4}, \mathrm{P}_{1} \times \mathrm{P}_{5}, \mathrm{P}_{1} \times \mathrm{P}_{6}, \mathrm{P}_{2} \times \mathrm{P}_{6}, \mathrm{P}_{2} \times \mathrm{P}_{7}, \mathrm{P}_{3} \times \mathrm{P}_{7}, \mathrm{P}_{4} \times \mathrm{P}_{7}\right.$ and $\mathrm{P}_{5} \times \mathrm{P}_{7}$ ) showed desirable Superiority percentage for 100-kernel weight.

For grain yield, The results in Table 8 indicated that, the values of superiority related to SC10 ranged from $-11.384 \%$ to $18.729 \%$ for crosses $\left(\mathrm{P}_{3} \mathrm{X}\right.$ $\left.\mathrm{P}_{7}\right)$ and $\left(\mathrm{P}_{5} \times \mathrm{P}_{7}\right)$, respectively. Above; results indicated that the single crosses; $\left(\mathrm{P}_{1} \times \mathrm{P}_{4}\right),\left(\mathrm{P}_{2} \times \mathrm{P}_{6}\right),\left(\mathrm{P}_{2} \times \mathrm{P}_{7}\right),\left(\mathrm{P}_{4} \times \mathrm{P}_{7}\right)$ and $\left(\mathrm{P}_{5} \times \mathrm{P}_{7}\right)$ were the best crosses for superiority relative to $\mathrm{SC} 10$ for the combined data. On the other side, superiority relative to $\mathrm{SC} 122$ ranged from -6.253 for $(\mathrm{P} 3 \times \mathrm{P} 7)$ to $25.604 \%$ for the cross $\left(\mathrm{P}_{5} \times \mathrm{P}_{7}\right)$. Above results indicated that the single crosses; $\left(\mathrm{P}_{1} \times \mathrm{P}_{4}\right),\left(\mathrm{P}_{1} \times \mathrm{P}_{5}\right)$, $\left(\mathrm{P}_{2} \times \mathrm{P}_{6}\right),\left(\mathrm{P}_{3} \times \mathrm{P}_{6}\right),\left(\mathrm{P}_{2} \times \mathrm{P}_{7}\right),\left(\mathrm{P}_{4} \times \mathrm{P}_{7}\right)$ and $\left(\mathrm{P}_{5} \times \mathrm{P}_{7}\right)$ were the best crosses for superiority relative to $\mathrm{SC} 122$. The obtained results are in good agreement with those reported by Hammouda (2002), Singh et al. (2002), El-Gazzar (2004), ELHosary \& EL-Badawy (2005) and Mosa (2006) where they comparing their crosses with chick cultivars and came to the same conclusions.

\section{Conclusion}

1- Gemmeiza location $\left(\mathrm{L}_{1}\right)$ was suitable location for traits; days to $50 \%$ silk and 100-kernel weight, while the suitable location for traits; grain yield, plant height and ear height was Sids location.

2- The density 21,000 plants/fed $\left(D_{2}\right)$ was more suitable for all studied traits , except grain yield, days to $50 \%$ silk were the density 26.250 plants/fed $\left(D_{1}\right)$ suitable more.

3- The inbred lines $\mathrm{P}_{1}, \mathrm{P}_{4}$ and $\mathrm{P}_{7}$ had desirable values and significant of GCA effects for most traits.

4- The crosses $\left(\mathrm{P}_{1} \times \mathrm{P}_{4}\right),\left(\mathrm{P}_{2} \times \mathrm{P}_{6}\right),\left(\mathrm{P}_{4} \times \mathrm{P}_{7}\right)$ and $\left(\mathrm{P}_{5} \times \mathrm{P}_{7}\right)$ considered the best crosses in most traits and could be used as good hybrids in maize breeding programs in most traits. 


\section{References}

Abd El-Aty, M.S. and Katta, Y.S. (2002) Estimation of heterosis and combining ability for yield and other agronomic traits in maize hybrids (Zea mays L.). J. Agric. Sci. Mansoura Univ. 27 (8), 5137-5146.

Aly, R.S.H. (1999) Genetical studies for some agronomical and technological characters of maize (Zea mays L.). M.Sc. Thesis, Faculty of Agriculture, Kafr El-Sheikh, Tanta University, Egypt.

Amer, E.A., El-Shenawy, A.A. and El-Zeir, F.A. (1998) Diallel analysis for ten inbred lines of maize. Egypt. J. Appl. Sci. 13, 79-91.

Barakat, A.A., El-Moula, M.A.A. and Ahmed, A.A. (2003) Combining ability for maize grain yield and its attributes under different environments. Assiut J. Agric. Sci. 34 (3), 15-25.

Barakat, A.A. and Osman, M.M.A. (2008) Gene action and combining ability estimates for some white promising maize inbred lines by top cross system. J. Agric. Sci., Mansoura Univ. 33, 6995-7009.

Choukan, R. (1999) General and specific combining ability often maize inbred lines for different traits in diallel cross. Seed Plant, 15, 280-295.

El-Absawy, E.A. (2002) Estimation of combining abilities and heterotic effects in maize. Minufiya J. Agric. Res. 27, 1363-1373.

El-Gazzar, A.I. (2004) Genetic variability in some maize inbred lines. M.Sc. Thesis, Fac. Agric., Mansoura Univ., Egypt.

EL-Hosary, A.A. and EI-Badawy, M.EI.M. (2005) Heterosis and combining ability in yellow corn (Zea mays L.) under two nitrogen levels. The $11^{\text {th }}$ Conf. Agron., Agron. Dept., Fac. of Agric., Assiut Univ., pp. 89-99.

El-Shenawy, A.A. and Tolba, S.A.E. (2001) General and specific combining ability and reciprocal crosses effects in complete diallel set of maize inbreds. J. Agric. Sci. Mansoura Univ. 26 (3), 1271-1279.

El-Shouny, K.A., EL-Bagoury, Olfat H., El-Sherbieny, H.Y. and Al-Ahmed, S.A. (2003) Combining ability estimates for yield and its components in yellow maize (Zea mays L.) under two plant densities. Egypt. J. Plant Breed, 7, 399-417.

Griffing, B. (1956) Concept of general and specific combining ability in relation to diallel crossing system. Australian J. Biol. Sci. 9, 463-493.

Hammouda, A.E.H. (2002) Genetic behaviour of some quantitative traits in maize (Zea mays L.). M Sc. Thesis, Fac. Agric. Moshtohor, Zagazig Univ., Egypt.

Marchao, R.L., Brasil, E.M., Duarte, J.B., Guimaraes, C.S. and Gomes, J.A. (2005) Plant density and agronomic traits of maize hybrids in narrow row spacing, Resqusia Agropecuaria Tropical, 35 (2), 93-101.

Egypt. J. Agron. 34, No. 2 (2012) 
Mosa, H.E. (2005) Combining ability of eight yellow maize (Zea mays L.) inbred lines for different characters in diallel crosses. J. Agric. Res. Tanta Univ. 31 (4-A), 604615.

Mosa, H.E. (2006) Diallel analysis of nine white maize inbred lines for different characters under different locations. J. Agric. Sci. Mansoura Univ. 31 (4), 2073-2080.

Mosa, H.E. and Amer, E.A. (2004) A diallel analysis among maize inbred lines for resistance to pink stem borer and grain yield under artificial infestation and non infestation. Annals of Agric. Sci., Moshtohor, 42 (2), 449-459.

Mosa, H.E. (1996) Studies on corn breeding. M.Sc. Thesis, Faculty of Agriculture, Kafr, El-Sheikh, Tanta University, Egypt.

Mosa, H.E. (2003) Heterosis and combining ability in maize (Zea mays L.). Minufiya, $J$. Agric. Res. 28, 1375-1386.

Mosa, H.E., El-Shenawy, A.A. and Motawei, A.A. (2006) Combining ability of white early maturity maize (Zea mays L.) germplasm. J. Agric. Res. Tanta Univ. 32 (2), 371-382.

Motawei, A.A. (2006) Gene action and heterosis in diallel crosses among ten inbred lines of yellow maize across various environments. Egypt. J. Plant Bred. 10 (1), 407-418.

Said, El. M. and Gabr, M.A. (1999) Response of some maize varieties to nitrogen fertilization and planting density. J. Agric. Sci. Mansoura Univ. 24 (4), 1665-1675.

Shafey, S.A., Yassien, H.E., El-Beially, I.E.M. and Gad-Alla, O.A.M. (2003) Estimates of combining ability and heterosis effects for growth, earliness and yield in maize (Zea mays L). J. Agric. Sci. Mansoura Univ. 28 (1), 55-67.

Singh, P.K. and Roy, A.K. (2007) Diallel analysis of inbred lines in maize. International J. of Agric. Sci. 3 (1), 213-216.

Singh, P.K., Chauhdary, L.B. and Akhtar, S.A. (2002) Heterosis in relation to combining ability in maize. J. Res. Birsa Agric. Univ. 14 (1), 37-43.

Soliman, F.H.S. and Sadek, S.E. (1999) Combining ability of new maize inbred lines and its utilization in the Egyptian hybrid program. Bull. Fac. Agric., Cairo Univ. 50, $1-20$.

Sprague, G.F. and Tatum, L.A. (1942) General vs. specific combining ability in single crosses of corn. J. Amer. Soc. Agron. 34, 923-932

Yousif, D.P., Ali, H.C. and Baker, R.H. (2003) Estimation of heterosis and combining ability in local maize inbred lines. Dirasat. Agric. Sci. 30 (2), 246-259. 


\section{تقدير القدرة على التآلف لبعض سلالات الذرة الشامية البيضاء الجديدة تحت ظروف بيئية مختلفـة}

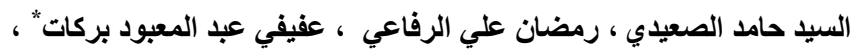

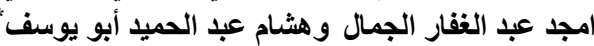

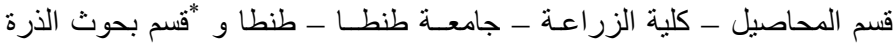

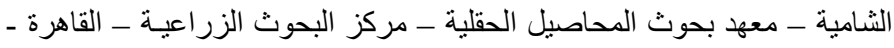

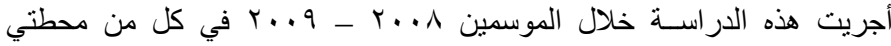

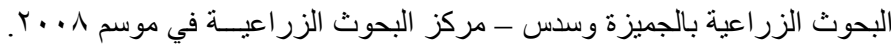

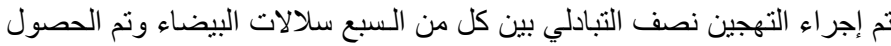

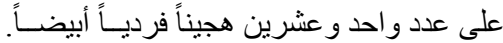

موسم 9 . . ب تم تقييم واحد و عشرين هجيناً فردياً ابيضاً بالإضافة إلى هجينين

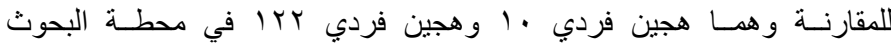

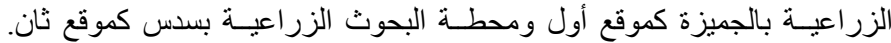

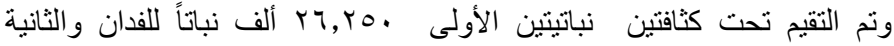

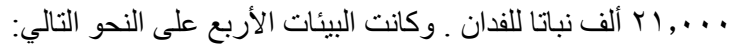

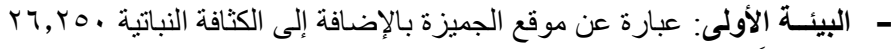
ألف نباتاً للفدان.

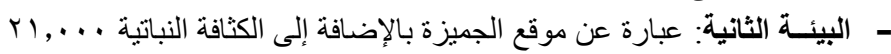
ألف نباتاً للفدان.

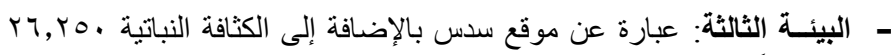
ألف نباتاً للفدان.

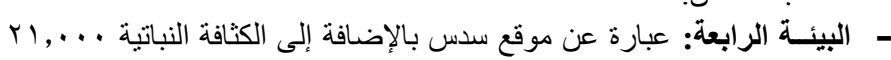
ألف نباتاً للفدان.

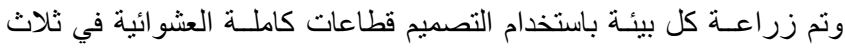

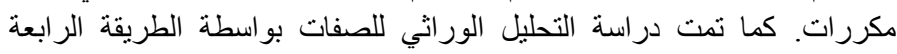

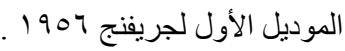

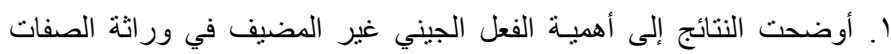

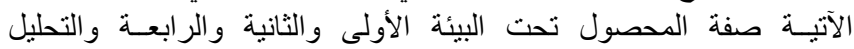

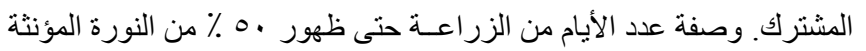

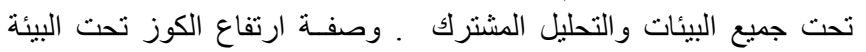

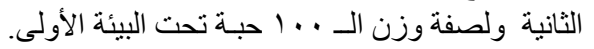

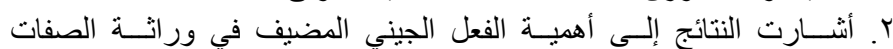

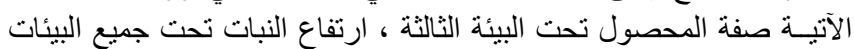

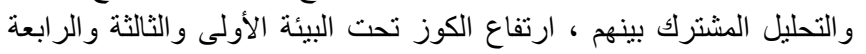

Egypt. J. Agron. 34, No. 2 (2012) 
ESTIMATION OF THE COMBINING ABILITY...

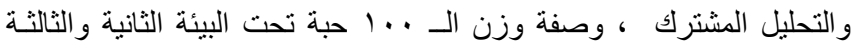

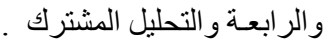

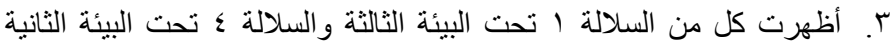

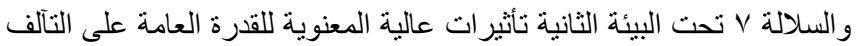

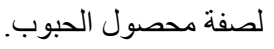

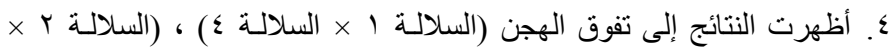

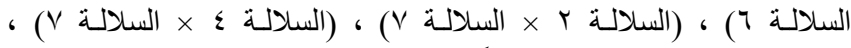

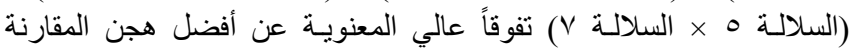

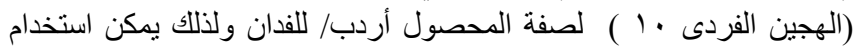

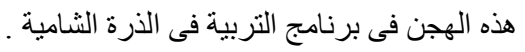

